\title{
Immune-enhanced Phagocytosis of Neisseria gonorrhoeae by Macrophages: Characterization of the Major Antigens to which Opsonins are Directed
}

\author{
By ROBERT B. JONES, $\dagger$ JOHN C. NEWLAND, DUANE A. OLSEN \\ AND THOMAS M. BUCHANAN* \\ Immunology Research Laboratory, U.S. Public Health Service Hospital, Seattle/ Departments \\ of Medicine and Pathobiology, University of Washington, 1131 14th Avenue South, Seattle, \\ Washington 98114 , U.S.A.
}

(Received 19 February 1980; revised 21 April 1980)

\begin{abstract}
Antisera were prepared in rabbits against whole organisms of colony type 1 Neisseria gonorrhoeae strains F62 and B (from gonococcal urethritis) and 7122 (a strain typical of those associated with disseminated gonococcal infection), and against purified outer membrane components from the same strains including pili and principal outer membrane protein. Antibody levels to pili, principal outer membrane protein and lipopolysaccharide were determined using a quantitative enzyme-linked immunosorbent assay. Each antiserum was heat-inactivated and tested for opsonic activity in a quantitative assay of phagocytosis. Each whole-organism antiserum was opsonic for its homologous strain, and this immuneenhanced phagocytosis was decreased by adsorption with homologous purified outer membrane components: pili $\gg$ lipopolysaccharide $\gg$ principal outer membrane protein. Opsonic activity was approximately equal for antiserum to purified pili and antiserum to the whole organisms for each of the three strains, and purified antibody to pili was highly opsonic. The $\mathrm{F}\left(\mathrm{ab}^{\prime}\right)_{2}$ fragments of antibody to pili were not opsonic, indicating a role for the Fc receptor on the phagocyte membrane in immune-enhanced phagocytosis of gonococci.
\end{abstract}

\section{INTRODUCTION}

The immune mechanisms capable of conferring protection against gonococcal infection have not been clearly defined. Potential roles have been suggested for bactericidal antibodies (Brooks et al., 1976; Buchanan et al., 1978; Kasper et al., 1977; McCutchan et al., 1976; Rice \& Kasper, 1977), for local secretory antibodies blocking attachment (O'Reilly et al., 1976; Tramont, 1977), and for opsonic antibodies (Ofek et al., 1974; Penn et al., 1977). That the latter might play a significant role is supported by the observation that virulent Type 1 organisms are more resistant to phagocytosis (Blake \& Swanson, 1975; Dilworth et al., 1975; Jones \& Buchanan, 1978; Punsalang \& Sawyer, 1973) and that opsonic antibody is acquired in some patients with gonorrhoea (Bisno et al., 1975). However, not all investigators have been able to demonstrate such antibody (Roberts, 1977). Furthermore, apparent survival of gonococci inside phagocytic cells has been reported (Evans, 1977; Witt et al., 1976) suggesting that phagocytosis might occasionally lead to a focus for persistent infection.

To better define immune-enhanced phagocytosis of gonococci, we examined three specific

$\dagger$ Present address: Departments of Medicine and Microbiology, University of Indiana, Indianapolis, Indiana. 
surface components and their interaction with opsonins for each of three different strains of Neisseria gonorrhoeae. Two strains were isolated from patients with acute gonococcal urethritis (strains F62 and B) and the third isolate was typical of those associated with disseminated gonococcal infection (strain 7122). Strain 7122 had the characteristic principal outer membrane protein (POMP) antigenic type (1975) and was resistant to killing by normal human serum (Schoolnik et al., 1976), as reported for strains causing disseminated gonococcal infection (Knapp \& Holmes, 1975) and/or asymptomatic urethral infection in males (Crawford et al., 1977). The surface components investigated were pili, POMP and lipopolysaccharide (LPS); in competitive inhibition tests the relative ability of each of these antigens to interact with opsonins was found to be pili $\gg$ LPS $\gg$ POMP.

\section{METHODS}

Strains of Neisseria gonorrhoeae. Strains which had been isolated from the urethra, cervix or pharynx of patients with gonococcal infection, and stored at $-70^{\circ} \mathrm{C}$ in $5 \%(\mathrm{w} / \mathrm{v})$ monosodium glutamate, $5 \%(\mathrm{w} / \mathrm{v})$ bovine serum albumin, were selectively subcultured until more than $90 \%$ of the colonies were stable as Type 1 colony types (Kellogg et al., 1963). Each strain was characterized as $N$. gonorrhoeae by oxidase, Gram stain and sugar fermentation reactions (Bodily et al., 1970). Minimal inhibitory concentrations for penicillin and nutritional requirements were determined according to Knapp \& Holmes (1975).

Strain 7122 (an endocervical isolate) was typical of strains causing disseminated gonococcal infection (DGI) in that it was resistant to the bactericidal activity of normal human serum (Schoolnik et al., 1976), had a common POMP serotype seen in about $90 \%$ of DGI strains (Hildebrandt \& Buchanan, 1978; Hildebrandt $e t$ al., 1978), had a minimal inhibitory concentration for penicillin of $\leqslant 0.015 \mu \mathrm{g} \mathrm{ml}^{-1}$ (Wiesner et al., 1973), and required arginine, hypoxanthine and uracil for growth (Crawford et al., 1977; Knapp \& Holmes, 1975). The other two strains, B and F62, lacked this growth requirement, were relatively resistant to penicillin with minimal inhibitory concentrations $\geqslant 0.125 \mu \mathrm{g} \mathrm{ml}^{-1}$, and were sensitive to the bactericidal activity of normal human serum. Each of the three strains had antigenically different pili (Buchanan, 1978), POMP (Buchanan et al., 1978) and LPS (N. L. von Jeney \& T. M. Buchanan, unpublished results).

Purification of outer membrane components. Pili were isolated from type 1 organisms and their purity was assessed after labelling with ${ }^{125} \mathbf{I}$ as described by Pearce \& Buchanan (1978). Pili were used for immunization or in competitive inhibition experiments only if the ratio of radiolabelled pili to any contaminating protein, as determined by sodium dodecyl sulphate (SDS)-polyacrylamide gel electrophoresis, was $\geqslant 10: 1$. These pili contained $<0.5 \%$ LPS by weight compared with total protein, as evaluated by assay for 2-keto-3-deoxyoctulosonic acid (KDO).

POMP was isolated from gonococcal outer membranes by a modification (Hildebrandt $e$ t al., 1978) of the method of Johnston et al. (1976). The resulting protein contained $<4 \%$ LPS by weight compared with total protein, as judged by assay for KDO, and consisted of $>90 \%$ POMP on SDS-polyacrylamide gel electrophoresis (Buchanan et al., 1977; Hildebrandt et al., 1978).

The LPS used for competitive inhibition experiments, for rabbit immunization and for coating ELISA tubes was isolated from gonococcal outer membrane preparations by suspending them in a $1.5 \%(\mathrm{w} / \mathrm{v})$ sodium deoxycholate, $5 \mathrm{~mm}$-EDTA, $50 \mathrm{~mm}$-glycine buffer, pH $9 \cdot 0$, followed by chromatography on a Sepharose 6B (Pharmacia) column as described for the isolation of POMP (Buchanan et al., 1978; Hildebrandt $e t$ al., 1978). The LPS-containing fractions were collected and the LPS was precipitated in $80 \%$ (v/v) ethanol, resuspended in the same buffer, and passed over a $1.5 \times 90 \mathrm{~cm}$ Sephadex G-75 (Pharmacia) column. The LPS-containing fractions were again collected and the LPS was reprecipitated in $80 \%$ ethanol and dried. LPS prepared in this manner was free of detectable protein, as assessed by SDS-polyacrylamide gel electrophoresis stained with Coomassie Blue (Pearce \& Buchanan, 1978) and by the method of Lowry using bovine serum albumin (Sigma) as a standard.

Preparation of antisera. Female rabbits were immunized by intramuscular inoculation of whole formalintreated type 1 organisms in complete Freund's adjuvant containing $2 \mathrm{mg}$ bacterial protein (Jones \& Buchanan, 1978). When a purified outer membrane component was the immunogen, $100 \mu \mathrm{g}$ pili protein, $100 \mu \mathrm{g}$ POMP protein or 100 to $200 \mu \mathrm{g}$ LPS was substituted for the whole organisms. Each rabbit was boosted after 3 weeks with the same antigen in incomplete Freund's adjuvant, and then weekly until high antibody levels were obtained, as assessed by capillary precipitin or slide agglutination reactions. Serum was collected 5 to $7 \mathrm{~d}$ after the final booster dose. The serum was filter-sterilized, heat-inactivated $\left(56^{\circ} \mathrm{C}\right.$ for $30 \mathrm{~min}$ ) and stored at $-70^{\circ} \mathrm{C}$ in $1.0 \mathrm{ml}$ portions until used.

Phagocytic assay. Phagocytosis of gonococci by mouse peritoneal macrophages was measured as previously 
described (Jones \& Buchanan, 1978). Briefly, ${ }^{3} \mathrm{H}$-labelled type 1 gonococci were incubated with a specific antiserum at a final concentration of $2 \%(\mathrm{v} / \mathrm{v})$, or with an equivalent volume of phosphate buffered saline (PBS), in tissue culture medium containing $10 \%(\mathrm{v} / \mathrm{v})$ heat-inactivated foetal-calf serum for $15 \mathrm{~min}$ at $37^{\circ} \mathrm{C}$. This gonococcal suspension was then added to a $35 \mathrm{~mm}$ Petri dish containing a coverslip coated with ${ }^{14} \mathrm{C}$-labelled macrophages. The number of macrophages per coverslip was approximately $3 \times 10^{5}$ and the number of gonococci in the $2.0 \mathrm{ml}$ suspension ranged from $5 \times 10^{6}$ to $5 \times 10^{7}$. After incubation with gentle swirling at $36^{\circ} \mathrm{C}$ for $15 \mathrm{~min}$, the coverslip was rinsed with PBS at $4^{\circ} \mathrm{C}$. The gonococci and the macrophages were solubilized and the activity of ${ }^{3} \mathrm{H}$ and ${ }^{14} \mathrm{C}$ was recorded. The specific activities of the macrophages and the gonococci were determined, and the number of colony-forming units (c.f.u.) per macrophage was calculated for each coverslip. Coverslips without macrophages were used to control for the non-specific adherence of gonococci to glass.

The standard deviation from the mean for the three coverslips in each experimental group never exceeded $30 \%$ of the mean and was usually approximately $10 \%$ of the mean.

In the competitive inhibition experiments, $1.0 \mathrm{ml} 20 \%(\mathrm{v} / \mathrm{v})$ antiserum in PBS was incubated with pili, POMP or LPS at $4{ }^{\circ} \mathrm{C}$ for $2 \mathrm{~h}$ prior to addition to the ${ }^{3} \mathrm{H}$-labelled gonococci.

ELISA for POMP, pili and LPS antibody levels. Purified antigens at concentrations of $2 \mu \mathrm{g} \mathrm{ml}^{-1} \mathrm{were}^{-1}$ used to coat polystyrene tubes and an enzyme-linked immunosorbent assay (ELISA) was performed on dilutions of the antiserum in PBS containing 0.05\% (v/v) Tween 20 (Buchanan, 1978; Hildebrandt et al., 1978). The range of dilutions was from $1: 100$ to $1: 100000$, and the dilution giving a specified absorbance reading when the results were plotted on semi-logarithmic paper was used for comparative purposes. The details of the pili-specific ELISA have been described previously (Buchanan, 1978) and the POMP-specific ELISA (Buchanan et al., 1978) and LPS-specific ELISA were similarly performed.

Affinity chromatography. Pili were coupled to CNBr-activated Sepharose CL-4B (Pharmacia) (300 mg $\mathrm{CNBr}$ per ml packed beads) by the method of Livingston (1974). Following incubation with pili for $18 \mathrm{~h}$ at $4{ }^{\circ} \mathrm{C}$, the beads were washed with 25 vol. $1 \mathrm{M}-\mathrm{NaCl}$ and then incubated with $1 \mathrm{M}$-glycine in $0 \cdot 2 \mathrm{M}-\mathrm{NaHCO}_{3}$, $\mathrm{pH} 9 \cdot 0$, for $2 \mathrm{~h}$ at room temperature to mask any remaining activated groups. The beads were then washed with 100 vol. $1 \mathrm{M}-\mathrm{NaCl}$ followed by 100 vol. distilled water and resuspended in PBS. Small columns containing $2 \mathrm{ml}$ Sepharose with covalently linked pili were poured in glass (Pasteur) pipettes, and antiserum to either whole organisms or purified pili was incubated in the column overnight at $4{ }^{\circ} \mathrm{C}$. After collecting twice the original volume of antiserum, the column was washed with 5 column vol. PBS. Then $4 \mathrm{ml} 3 \mathrm{M}-\mathrm{NaI}, \mathrm{pH} 6 \cdot 8$, was passed over the column. The column was washed twice with PBS, and a total of $10 \mathrm{ml}$ eluate was collected. The $\mathrm{NaI}$ eluate was dialysed against $0.15 \mathrm{M}-\mathrm{NaCl}, 0.01 \mathrm{M}-\mathrm{NaH}_{2} \mathrm{PO}_{4}$ buffer, $\mathrm{pH} 7.0$, for $18 \mathrm{~h}$ and pervaporated to a final volume of $2 \mathrm{ml}$. The columns were finally washed with 10 column vol. PBS and stored in PBS, $0.02 \%$ sodium azide. Control columns were prepared by coupling crystalline bovine serum albumin (Sigma) to CNBr-activated Sepharose CL-4B as described above and were run in parallel to the pili columns.

$F\left(a b^{\prime}\right)_{2}$ fragment preparation. Immunoglobulin $\mathrm{G}$, specific for $\mathrm{F} 62$ pili, was prepared from whole antiserum to F62 pili by ammonium sulphate precipitation followed by passage over a DEAE-cellulose column (Livingston, 1974). The IgG $\left(10 \mathrm{mg} \mathrm{ml}^{-1}\right)$ was cleaved using pepsin (Worthington Biochemical Corp., Freehold, N.J., U.S.A.) according to the method of Nisonoff \& Rivers (1961). F( $\left.\mathrm{ab}^{\prime}\right)_{2}$ fragments, following dialysis against the column buffer $(0.1 \mathrm{M}$-Tris $/ \mathrm{HCl}, 0.2 \mathrm{M}-\mathrm{NaCl}, 0.002 \mathrm{M}-\mathrm{EDTA}, \mathrm{pH} 7 \cdot 7)$, were purified according to the method of Stanworth \& Turner (1978) which consists of passing the mixture over a Sephadex G-150 (Pharmacia) column followed by re-chromatography of selected fractions over a Sephadex G-200 column. Antigen-binding activity and confirmation of the absence of an Fc region were demonstrated by Ouchterlony immunodiffusion precipitation using purified pili and antiserum to the Fc region of IgG (Miles Laboratories).

\section{RESULTS}

\section{Competitive inhibition of opsonization}

As non-piliated gonococci are readily phagocytosed even in the absence of antisera, and piliated gonococci are almost totally resistant to phagocytosis in the presence of heatinactivated normal rabbit serum (Dilworth et al., 1975; Jones \& Buchanan, 1978), the opsonic activity of a given serum can only be demonstrated with well piliated organisms. Therefore, each phagocytosis experiment was performed with organisms that had been selectively subcultured for $3 \mathrm{~d}$ previously to enhance piliation. Maximum opsonic activity of a given serum was demonstrable when $>95 \%$ of the gonococci phagocytosed were piliated, and the bacterial concentration was approximately 20 to 50 gonococci per 
Table 1. Competitive inhibition of opsonic activity of antiserum to whole organisms by homologous purified pili

In each assay, a single strain of piliated gonococci (F62, B or 7122) was used, together with homologous antiserum to whole organisms [or normal rabbit serum, or phosphate-buffered saline (PBS, control)]. Homologous purified pili were used for inhibition of opsonization.

\begin{tabular}{lcccc}
\multicolumn{1}{c}{ Serum } & Pili & Strain F62 & Strain B & Strain 7122 \\
\cline { 4 - 5 } & - & 0.14 & 0.01 & 0.03 \\
PBS & - & 0.84 & 2.46 & 0.70 \\
Homologous antiserum & $150 \mu \mathrm{g}$ & 0.40 & 0.35 & 0.59 \\
Homologous antiserum & - & 0.21 & 0.16 & 0.16
\end{tabular}

* Each result represents the mean for three coverslips; the standard deviation was always $\leqslant 30 \%$ of the mean.

Table 2. Competitive inhibition of opsonization of strain $\mathrm{B}$ by homologous and heterologous pili

Piliated strain B and antiserum to whole organisms of strain B were used in phagocytosis assays. Purified pili were added as indicated.

\begin{tabular}{lcc}
\multicolumn{1}{c}{ Serum } & Pili & $\begin{array}{c}\text { Phagocytosis* } \\
\text { (c.f.u. per macrophage) }\end{array}$ \\
PBS & - & 0.01 \\
Antiserum to B & - & 2.46 \\
Antiserum to B & B, $150 \mu \mathrm{g}$ & 0.35 \\
Antiserum to B & $7122,150 \mu \mathrm{g}$ & 3.69 \\
Antiserum to B & $\mathrm{F} 62,150 \mu \mathrm{g}$ & 2.69 \\
Normal rabbit serum & - & 0.16
\end{tabular}

* Each result represents the mean for three coverslips; the standard deviation was always $\leqslant 30 \%$ of the mean.

macrophage. With larger concentrations, non-piliated gonococci within the suspension were phagocytosed, and the differences in opsonic activity between immune and normal rabbit sera were reduced. Heterologous antisera produced 10 to $50 \%$ of the opsonization of homologous antisera. Therefore, homologous antisera were used to evaluate which surface components of gonococci were reacting with opsonic antibodies. The increase in c.f.u. per macrophage obtained with immune serum represented increased phagocytosis rather than increased surface attachment, since inhibitors of phagocytosis blocked this increase (Jones \& Buchanan, 1978).

Homologous pili were effective in inhibiting $(\geqslant 70 \%)$ but not abolishing the opsonic activity of antisera prepared against whole organisms of strains B and F62 (Table 1). However, the same quantity of pili was less effective at inhibiting $(20 \%)$ the opsonization of strain 7122 .

Heterologous pili used in the same concentration as homologous pili produced no inhibition (Table 2) suggesting a considerable antigenic specificity to the opsonic activity of each rabbit anti-pilus antiserum.

Preincubation of $1.5 \mathrm{mg}$ of homologous purified, protein-free LPS in $1.0 \mathrm{ml}$ of a $1: 5$ dilution in PBS of antiserum prepared against whole organisms resulted in some inhibition $(\geqslant 37 \%)$ of opsonic activity in the homologous antiserum for all three strains tested (Table 3). This inhibition was reduced to $\geqslant 20 \%$ when $0.15 \mathrm{mg}$ of homologous LPS was used to inhibit phagocytosis (Table 3). Heating the LPS at $100^{\circ} \mathrm{C}$ for $30 \mathrm{~min}$ did not significantly reduce its ability to inhibit opsonization. Inhibition of opsonization by 


\section{Table 3. Inhibition of immune-enhanced phagocytosis produced by homologous LPS}

Assays were carried out as in Table 1, using homologous antiserum to whole organisms. Homologous purified LPS was used for inhibition of phagocytosis.

\begin{tabular}{lcccc}
\multirow{2}{*}{ Serum } & LPS & Strain F62 & Strain B & Strain 7122 \\
\cline { 3 - 5 } PBS & - & 0.14 & 0.04 & 0.02 \\
Homologous antiserum & - & 0.87 & 0.58 & 0.68 \\
Homologous antiserum & $1.5 \mathrm{mg}$ & 0.05 & 0.41 & 0.30 \\
Homologous antiserum & $0.15 \mathrm{mg}$ & 0.16 & 0.49 & 0.41 \\
Normal rabbit serum & - & 0.04 & 0.13 & 0.07
\end{tabular}

* Each result represents the mean for three coverslips; the standard deviation was always $\leqslant 30 \%$ of the mean.

Table 4. Opsonic activity of antisera prepared against specific outer membrane components and whole organisms

For each serum, levels of antibody to homologous POMP, pili and LPS were determined by ELISA. Piliated gonococci (strain F62, B or 7122) and homologous antisera were used in phagocytosis assays.

Phagocytosis $\dagger$

Antibody level to different antigens*

\begin{tabular}{ll} 
Strain & \multicolumn{1}{c}{ Serum } \\
F62 & PBS \\
& Normal rabbit serum \\
& Anti-whole organism \\
& - Anti-POMP \\
& Anti-pilus \\
B & PBS \\
& Normal rabbit serum \\
& Anti-whole organism \\
& Anti-POMP \\
& Anti-pilus \\
7122 & PBS \\
& Normal rabbit serum \\
& Anti-whole organism \\
& Anti-POMP \\
& Anti-pilus
\end{tabular}

\begin{tabular}{rrr} 
POMP & \multicolumn{1}{c}{ Pili } & \multicolumn{1}{c}{ LPS } \\
-100 & -100 & -100 \\
21000 & 10200 & 11000 \\
50000 & 540 & 6800 \\
1200 & 70000 & 1000 \\
- & - & - \\
100 & 100 & 100 \\
13000 & 2900 & 5100 \\
17000 & 100 & 7200 \\
900 & 5000 & 100 \\
- & - & - \\
100 & 100 & 100 \\
10000 & 6700 & 1000 \\
111000 & 100 & 420 \\
5500 & 30000 & 570
\end{tabular}

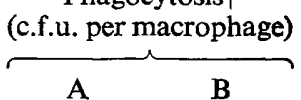

A

$0 \cdot 10$

$0.07 \quad 0.16$

$0.25 \quad 1.05$

$0.05 \quad 0.13$

$0.29 \quad 1 \cdot 22$

$0.05 \quad 0.01$

$0.05 \quad 0.10$

$5 \cdot 71 \quad 3 \cdot 01$

$1 \cdot 10 \quad 0 \cdot 36$

$5 \cdot 10 \quad 4 \cdot 35$

$0.01 \quad 0.01$

$0.04 \quad 0.04$

$0.54 \quad 0.31$

$0.06 \quad 0.08$

$0.67 \quad 0.59$

* Reciprocal of serum dilution giving an $A_{490}$ of 0.400 in ELISA.

$\dagger$ Each result represents the mean for three coverslips; the standard deviation was always $\leqslant 30 \%$ of the mean. Columns A and B represent two separate experiments on different days; the difference in results between the columns is probably due to differences in the exact extent of piliation and the ratio of bacteria to macrophages. Thus, results are only comparable within each column.

heterologous LPS was variable, but in general it correlated with whether the heterologous LPS shared antigenic determinants with the LPS of the test strain.

Purified heterologous POMP in amounts up to $1 \mathrm{mg}$ produced $\leqslant 15 \%$ inhibition of opsonization for each of the three strains tested.

\section{Opsonic activity of specific antisera}

Antiserum prepared against whole type 1 organisms was uniformly opsonic and contained antibodies measurable by ELISA against three major surface antigens - POMP, pili and LPS (Table 4). Antiserum to purified pili was equally opsonic for each of the three strains tested, and the opsonic effect was equal or superior to that produced by antiserum 


\section{Table 5. Opsonic activity of homologous purified anti-pilus antibody}

Piliated gonococci (strain F62, B or 7122) and homologous antiserum or purified anti-pilus antibody (eluate from affinity columns) were used in phagocytosis assays.

\begin{tabular}{|c|c|c|c|c|c|c|}
\hline \multirow[b]{2}{*}{ Serum or antibody } & \multicolumn{2}{|c|}{ Strain F62 } & \multicolumn{2}{|c|}{ Strain 7122} & \multicolumn{2}{|c|}{ Strain B } \\
\hline & $\begin{array}{l}\text { Anti-pilus } \\
\text { antibody } \\
\text { level* }\end{array}$ & $\begin{array}{l}\text { Phagocytosis } \dagger \\
\text { (c.f.u. per } \\
\text { macrophage) }\end{array}$ & $\begin{array}{c}\text { Anti-pilus } \\
\text { antibody } \\
\text { level* }\end{array}$ & $\begin{array}{l}\text { Phagocytosis } \dagger \\
\text { (c.f.u. per } \\
\text { macrophage) }\end{array}$ & $\begin{array}{l}\text { Anti-pilus } \\
\text { antibody } \\
\text { level* }\end{array}$ & $\begin{array}{l}\text { Phagocytosis } † \\
\text { (c.f.u. per } \\
\text { macrophage) }\end{array}$ \\
\hline PBS & - & 0.02 & 一 & 0.01 & - & 0.01 \\
\hline Anti-whole organism & 2900 & $0 \cdot 19$ & 6800 & $0 \cdot 24$ & 2300 & $2 \cdot 73$ \\
\hline Anti-pilus antibody & 1300 & $0 \cdot 11$ & 4100 & $0 \cdot 16$ & 940 & 0.50 \\
\hline BSA control eluate & 100 & 0.02 & 500 & 0.08 & 500 & 0.01 \\
\hline Normal rabbit serum & 100 & 0.03 & 500 & 0.06 & 500 & 0.03 \\
\hline
\end{tabular}

* Reciprocal of serum dilution giving an $A_{490}$ of 0.400 in ELISA.

$\dagger$ Each result represents the mean for three coverslips; the standard deviation was always $\leqslant 30 \%$ of the mean.

Table 6. Opsonic activity of antiserum to purified $\mathrm{F} 62$ pili, and of the $\operatorname{Ig} G$ and $F\left(a b^{\prime}\right)_{2}$ portions of this antiserum

Piliated strain F62 gonococci and homologous antiserum or its components were used in phagocytosis assays.

\begin{tabular}{lcc}
\cline { 2 - 2 } \multicolumn{1}{c}{ Serum component } & Experiment 1 & Experiment 2 \\
PBS & 0.02 & 0.02 \\
Column buffer & 0.04 & 0.02 \\
Anti-pilus antiserum & 1.60 & 0.67 \\
IgG from anti-pilus antiserum & 2.59 & 2.01 \\
F(ab' ${ }_{2}$ from IgG of anti-pilus antiserum & 0.16 & 0.07
\end{tabular}

* Each result represents the mean for three coverslips; the standard deviation was always $\leqslant 30 \%$ of the mean.

to whole organisms. Homologous anti-POMP antiserum, which contained very low levels of anti-pilus antibody, was not more opsonic than normal rabbit serum for F62, and showed only slight opsonic activity for the other two strains (Table 4). Purified LPS proved to be a poor immunogen in the system used and resulted in lower levels of antibody to LPS than those obtained in corresponding anti-whole organism antiserum. Therefore, the role of LPS as an antigen to react with opsonins was evaluated only by inhibition of the opsonic activity of anti-whole organism antisera using highly purified LPS (Table 3 ).

\section{Opsonic activity of purified antibody to pili}

Purified antibody to pili, prepared by affinity chromatography, showed no activity against either LPS or POMP as measured by ELISA. This purified antibody to pili was opsonic for its homologous strain. The amount of immune-enhanced phagocytosis produced by antiserum to whole organisms or by purified antibody to pili correlated with the amount of antibody to pili in each antibody preparation (Table 5).

\section{Opsonic activity of $F\left(a b^{\prime}\right)_{2}$ fragments}

The $F\left(a b^{\prime}\right)_{2}$ fragments of IgG antibody to pili had little or no opsonic activity for $F 62$ piliated gonococci (Table 6). This indicates that the opsonic activity of the IgG of anti-pilus antibody is mediated via recognition by human polymorphonuclear leucocytes of the Fc 
portion of IgG molecules bound to gonococcal pili. Thus, intact IgG antibody molecules to pili are opsonic, but pilus-binding $F\left(a b^{\prime}\right)_{2}$ fragments are not opsonic. If pili were nonspecific inhibitors of phagocytosis, $\mathrm{F}\left(\mathrm{ab}^{\prime}\right)_{2}$ might be expected to nullify the antiphagocytic effect. Such an effect of $F\left(a b^{\prime}\right)_{2}$ fragments was not observed (Table 6), and heterologous pili added to phagocytosis assays were poor inhibitors of the immune enhancement, suggesting that pili are not non-specific inhibitors of phagocytosis (Table 2).

\section{DISCUSSION}

The results suggest that anti-pilus antibodies are the main opsonins for the one DGI and the two non-DGI strains of $N$. gonorrhoeae tested. When whole organisms (strains F62 and B) were used to immunize rabbits, antibodies were produced against each of three major surface components - POMP, pili and LPS - and this antiserum was opsonic. Its opsonic activity was significantly reduced by competitive inhibition primarily with antigenically homologous pili, and to a lesser extent with homologous LPS (Tables 1, 2 and $3)$. When opsonic activity was compared with antibody levels against specific antigens (Table 4), the degree of opsonic activity of each antiserum for these three strains correlated most closely with the anti-pilus antibody levels. Furthermore, purified anti-pilus antibody of each strain was highly opsonic, and produced immune-enhanced phagocytosis $2 \cdot 7-$ to 16-fold higher than normal rabbit serum (Table 5).

These experiments suggest that pili are an important antigen to be included in any vaccine designed to produce opsonic antibody. Still unresolved is the relative importance of antigenic heterogeneity of pili. For example, what will be the effect of human antiserum to F62 pili upon the phagocytosis of gonococci possessing pili that differ antigenically from F62 pili? This question will be best answered using human polymorphonuclear leucocytes in a quantitative assay of phagocytosis.

This research was supported in part by grant RO1-AI-13149, and contracts NO1-AI-52535 and NO1-AI-92618, and by training grant AI-07044 from the National Institute of Allergy and Infectious Diseases, NIH, Bethesda, Maryland, and by Federal Health Program Service Project SEA 76-43.

Article no. 31 from the Immunology Research Laboratory, U.S. Public Health Service Hospital, Seattle.

\section{REFERENCES}

Bisno, A. L., Ofek, I., Beachey, E. H., Chandler, R. W. \& Curran, J. W. (1975). Human immunity to Neisseria gonorrhoeae: acquired serum opsonic antibodies. Journal of Laboratory and Clinical Medicine 86, 221-229.

Blake, M. \& Swanson, J. (1975). Studies on gonococcus infection. IX. In vitro decreased association of pilated gonococci with mouse peritoneal macrophages. Infection and Immunity 11, 1402-1404.

Bodily, H. S., Updyke, E. L. \& Mason, J. W. (editors) (1970). Diagnostic Procedures for Bacterial, Mycotic and Parasitic Infections, p. 296. New York: American Public Health Association. Brooks, G. F., Israel, K. S. \& Petersen, B. H. (1976). Bactericidal and opsonic activity against Neisseria gonorrhoeae in sera from patients with disseminated gonococcal infection. Journal of Infectious Diseases 134, 450-462.

Buchanan, T. M. (1978). Antigen-specific sero- typing of Neisseria gonorrhoeae. I. Use of an Enzyme Linked ImmunoSorbent Assay to quantitate pilus antigens on gonococci. Journal of Infectious Diseases 138, 319-325.

Buchanan, T. M., Pearce, W. A., Schoolnik, G. K. \& ARKo, R. J. (1977). Protection against infection with Neisseria gonorrhoeae by immunization with outer membrane protein complex and purified pili. Journal of Infectious Diseases 136, S132-S137.

Buchanan, T. M., Chen, K. C. S., Jones, R. B., Hildebrandt, J. F., Pearce, W. A., Hermodson, M. A., Newland, J. C. \& Luchtel, D. L. (1978). Pili and principal outer membrane protein of Neisseria gonorrhoeae: immunochemical, structural and pathogenic aspects. In Immunobiology of Neisseria gonorrhoeae, pp. 145-154. Edited by G. F. Brooks, E. C. Gotschlich, K. K. Holmes, W. D. Sawyer \& F. E. Young. Washington, D.C.: American Society for Microbiology. 
Crawford, G., Knapp, J. S., Hale, J. \& Holmes, K. K. (1977). Asymptomatic gonorrhea in men: caused by gonococci with unique nutritional requirements. Science 196, 1352-1353.

Dilworth, J. A., Hendley, J. O. \& Mandell, G. L. (1975). Attachment and ingestion of gonococci by human neutrophils. Infection and Immunity 11, 512-516.

Evans, B. A. (1977). Ultrastructural study of cervical gonorrhea. Journal of Infectious Diseases 136, 248-255.

Hildebrandt, J. F. \& Buchanan, T. M. (1978). Identification of an outer membrane protein associated with gonococci capable of causing disseminated infection. In Immunobiology of Neisseria gonorrhoeae, p. 128. Edited by G. F. Brooks, E. C. Gotschlich, K. K. Holmes, W. D. Sawyer \& F. E. Young. Washington, D.C.: American Society for Microbiology.

Hildebrandt, J. F., Mayer, L. W., Wang, S. P. \& BUCHANAN, T. M. (1978). Neisseria gonorrhoeae acquire a new principal outer membrane protein when transformed to resistance to serum bactericidal activity. Infection and Immunity 20, 267-273.

Johnston, K. H., Holmes, K. K. \& Gotschlich, E. C. (1976). The serologic classification of Neisseria gonorrhoeae. I. Isolation of the outer membrane complex responsible for serotype specificity. Journal of Experimental Medicine 143, 741-758.

JoNEs, R. B. \& Buchanan, T. M. (1978). Quantitative measurement of phagocytosis of Neisseria gonorrhoeae by mouse peritoneal macrophages. Infection and Immunity 20, 732-738.

Kasper, D. L., Rice, P. A. \& MCCormaCk, W. M. (1977). Bactericidal antibody in genital infection due to Neisseria gonorrhoeae. Journal of Infectious Diseases 135, 243-251.

Kellogg, D. S., JR, Peacock, W. L., JR, Deacon, W. E., Brown, L. \& PIRKel, C. I. (1963). Neisseria gonorrhoeae. I. Virulence genetically linked to clonal variation. Journal of Bacteriology 85, 1274-1279.

KNaPP, J. S. \& Holmes, K. K. (1975). Disseminated gonococcal infections caused by Neisseria gonorrhoeae with unique nutritional requirements. Journal of Infectious Diseases 132, 204-208.

Livingsion, D. M. (1974). Immunoaffinity chromatography of proteins. Methods in Enzymology 34B, 725-731.

McCutchan, J. A., Levine, S. \& Braude, W. I. (1976). Influence of colony type on susceptibility of gonococci to killing by human serum. Journal of Immunology 116, 1652-1655.

Nisonoff, A. \& Rivers, M. M. (1961). Recombination of a mixture of univalent antibody fragments of different specificities. Archives of Biochemistry and Biophysics 93, 460-466.

OfeK, I., BeACHeY, E. H. \& BisNo, A. L. (1974). Resistance of Neisseria gonorrhoeae to phagocytosis: relationship to colonial morphology and surface pili. Journal of Infectious Diseases 129, 310-316.

O'Reilly, R. J., Lee, L. \& Welch, B. J. (1976). Secretory $\operatorname{IgA}$ antibody responses to Neisseria gonorrhoeae in the genital secretions of infected females. Journal of Infectious Diseases 133, 113-125.

Pearce, W. A. \& Buchanan, T. M. (1978). Attachment role of gonococcal pili. Optimum conditions and quantitation of adherence of isolated pili to human culls in vitro. Journal of Clinical Investigation 61, 931-943.

Penn, C. W., Parsons, N. J., Sen, D., Veale, D. R. \& SMITH, H. (1977). Immunization of guinea pigs with Neisseria gonorrhoeae: strain specificity and mechanisms of immunity. Journal of General Microbiology 100, 159-166.

Punsalang, A. P., JR \& Sawyer, W. D. (1973). Role of pili in the virulence of Neisseria gonorrhoeae. Infection and Immunity 8, 255-263.

RICE, P. A. \& KASPER, D. L. (1977). Characterization of gonococcal antigens responsible for induction of bactericidal antibody in disseminated infection. Journal of Clinical Investigation 60, 1149-1158.

RoBERTs, R. B. (1977). Gonococci-leukocyte interactions. In The Gonococcus, pp. 334-339. Edited by R. B. Roberts. New York: John Wiley.

SChoolnik, G. K., Buchanan, T. M. \& Holmes, K. K. (1976). Gonococci causing disseminated gonococcal infection are resistant to the bactericidal action of normal human sera. Journal of Clinical Investigation 58, 1163-1173.

Stanworth, D. R. \& Turner, M. W. (1978). Immunochemical analysis of immunoglobulins and their subunits. In Handbook of Experimental Immunology, 3rd edn, vol. 1, pp. 6.19-6.24. Edited by D. M. Weir. Oxford: Blackwell Scientific Publications.

Tramont, E. C. (1977). Inhibition of adherence of Neisseria gonorrhoeae by human genital secretions. Journal of Clinical Investigation 59, 117-124.

Wiesner, P. J., Handsfield, H. H. \& Holmes, K. K. (1973). Low antibiotic resistance of gonococci causing disseminated infection. $\mathrm{New}$ England Journal of Medicine 288, 1221-1222.

Witt, K., Veale, D. R., Finch, H., PenN, C. W., SEN, D. \& SMITH, H. (1976). Resistance of Neisseria gonorrhoeae grown in vitro to ingestion and digestion by phagocytes of human blood. Journal of General Microbiology 96, 341-350. 